\title{
Direct and Indirect Inhibition by Catecholamines of Hypocretin/Orexin Neurons
}

\author{
Ying Li and Anthony N. van den Pol \\ Department of Neurosurgery, Yale University School of Medicine, New Haven, Connecticut 06520
}

\begin{abstract}
Hypothalamic hypocretin enhances arousal, similar to the actions of norepinephrine (NE). The physiological actions of NE were examined in hypocretin neurons identified by selective green fluorescent protein expression in transgenic mouse hypothalamic slices using whole-cell recording. NE induced an outward current, inhibited spike frequency, and hyperpolarized hypocretin neurons dose dependently. Similar actions were evoked by the selective $\alpha 2$ adrenergic agonist clonidine. The $\alpha 2$ antagonist idazoxan increased spike frequency, suggesting tonic NE-mediated inhibition. The NE-induced current was inwardly rectified, and the reversal potential was dependent on external potassium concentration; it was blocked by barium in the bath and by GTP- $\gamma$-S in the pipette, suggesting activation of a G-protein inward rectifying $\mathrm{K}^{+}$(GIRK) current. $\mathrm{NE}$ and clonidine decreased calcium currents evoked by depolarizing voltage steps. The selective $\alpha 1$ adrenergic agonist phenylephrine had no effect on membrane potential but did increase IPSC frequency; miniature IPSC frequency was also increased, in some cells without any effect on amplitude, suggesting a facilitative presynaptic action at $\alpha 1$ receptors on GABAergic axons that innervate hypocretin neurons. NE therefore inhibits hypocretin neurons directly through two mechanisms: activation of a GIRK current, depression of calcium currents, and indirectly through increased inhibitory GABA input. Similar to NE, dopamine and epinephrine reduced or blocked spikes and, in the presence of TTX, showed direct hyperpolarizing actions. The action of dopamine was blocked by the D2 receptor antagonist eticlopride, whereas a D1/5 antagonist had no effect. These data suggest that catecholamines evoke strong inhibitory actions on hypocretin neurons and suggest negative feedback from catecholamine cells that may be excited by hypocretin.
\end{abstract}

Key words: arousal; dopamine; patch clamp; sleep; lateral hypothalamus; norepinephrine; food intake

\section{Introduction}

Hypocretin/orexin neurons are found in the lateral hypothalamus/perifornical area. Hypocretin injections into the brain enhance arousal (Hagan et al., 1999). Loss of the peptide or its receptors can result in narcolepsy in rodents, dogs, and humans (Chemelli et al., 1999; Lin et al., 1999; Nishino et al., 2000). Axons from the hypocretin cells project widely throughout the CNS (Peyron et al., 1998; van den Pol, 1999) with a high level of innervation in some select brain regions. One region that receives a dense hypocretin innervation is the locus ceruleus (LC). Most of the LC neurons synthesize norepinephrine (NE) and, similar to the hypocretin neurons, send axons to many regions of the brain including the lateral hypothalamus region where hypocretin cells are located. NE-containing axons are found in apparent contact with hypocretin neurons (Baldo et al., 2003). The hypocretin neurons also send a strong excitatory projection to regions of the brain that synthesize the catecholamines dopamine and epinephrine, which may also play a role in arousal, and these cells in turn project to the hypothalamus (de Lecea et al., 1998; Peyron et al., 1998; Wisor et al., 2001; Kaslin et al., 2004).

Received July 15, 2004; revised Nov. 9, 2004; accepted Nov. 10, 2004.

This work was supported by National Institutes of Health Grants NS37788, NS41454, and AI/NS48854. We thank Dr. Claudio Acuna-Goycolea for helpful suggestions on this manuscript.

Correspondence should be addressed to Dr. Anthony N. van den Pol, Department of Neurosurgery, Yale University School of Medicine, 333 Cedar Street, New Haven, CT 06520. E-mail: Anthony.vandenpol@yale.edu. DOl:10.1523/JNEUROSCI.4015-04.2005

Copyright $\odot 2005$ Society for Neuroscience $\quad$ 0270-6474/05/250173-11\$15.00/0
Hypocretin-immunoreactive axons make direct synaptic contact with the noradrenergic neurons of the LC (Horvath et al., 1999). At the cellular level, a number of studies have shown a strong excitatory action of hypocretin on LC (Hagan et al., 1999; Horvath et al., 1999; Bourgin et al., 2000; Marcus et al., 2001), in the nucleus of the solitary tract (Smith et al., 2002), another source of noradrenergic projections to the hypothalamus, and in the ventral tegmental area, where dopamine cells are localized (Korotkova et al., 2003). Hypocretin increases the synchronization of firing of individual NE-containing LC neurons (van den Pol et al., 2002), which may enhance cognitive arousal.

The central noradrenergic system is involved in the control of arousal (Foote and Morrison, 1987; Saper et al., 2001; Mallick et al., 2002; Berridge and Waterhouse, 2003). LC neurons fire fastest during wakefulness, slow down with the EEG during non-rapid eye movement (REM) sleep, and nearly stop firing during REM sleep (Aston-Jones et al., 1991). NE is involved in selective attention (Selden et al., 1990a,b), exploratory behavior, and responsiveness to novelty (Booth, 1967; Sara et al., 1995). NE may also play a role in food intake (Booth, 1967; Alexander et al., 1993; Bray, 2000; Wellman, 2000).

Recent reports showed that NE inhibits hypocretin neurons, but no mechanisms of action were elucidated ( $\mathrm{Li}$ et al., 2002; Yamanaka et al., 2003a). Here, using whole-cell voltage- and current-clamp recording, we studied the direct and indirect mechanisms by which NE and other catecholamines modulate hypocretin neurons. 


\section{Materials and Methods}

Hypothalamic slices were prepared from postnatal 2- to 9-week-old hypocretin-transgenic mice (kindly provided by Dr. T. Sakurai, University of Tsukuba, Tsukuba, Japan) that expressed green fluorescent protein (GFP) selectively in hypocretin neurons ( $\mathrm{Li}$ et al., 2002; Yamanaka et al., 2003b); most of the slices used were taken from mice 2-3 weeks of age. Briefly, mice maintained on a $12 \mathrm{hr}$ light/dark cycle were anesthetized with pentobarbital sodium (Nembutal; $80 \mathrm{mg} / \mathrm{kg}$, i.p.) during daylight hours and then decapitated. The brain containing the lateral hypothalamus was rapidly removed and immersed in ice-cold, oxygenated artificial CSF (ACSF) before being trimmed to a hypothalamic block. The hypothalamic block was then glued on the plate of a vibratome, and 220 - to $280-\mu \mathrm{m}$-thick coronal slices were cut in ice-cold, oxygenated ACSF. Then they were transferred to a chamber filled with oxygenated ACSF and kept at room temperature $\left(22^{\circ} \mathrm{C}\right)$ for $1-2 \mathrm{hr}$ before recording.

The slice was placed in the center of a recording chamber on the stage of an upright microscope (BX50WI; Olympus, New Hyde Park, $\mathrm{NY}$ ) that had infrared differential interference contrast condenser and fluorescence capability. Then it was immobilized with a tungsten screen. The volume of the recording chamber was $\sim 0.5 \mathrm{ml}$. Patch pipettes were made of borosilicate glass (World Precision Instrument, Sarasota, FL) by a vertical pipette puller (Narashige PP-83; Narishige, Tokyo, Japan). The resistance of the pipette was 4-6 M $\Omega$ after being filled with the pipette solution. All recordings were obtained at $32-33^{\circ} \mathrm{C}$. The signals were amplified with the EPC-9 amplifier (Heka, Lambrecht, Germany). Data were sampled at 1 $\mathrm{kHz}$ with Pulse 8.5 software (Heka) and only accepted when series resistance was $<20 \mathrm{M} \Omega$ and changed $<15 \%$ during recording. Data were analyzed with PulseFit, Axograph 4.5 (Axon Instruments, Union City, CA), and Igor Pro (WaveMetrics, Lake Oswego, OR) software as described previously (Gao and van den Pol, 1999). The frequency of action potentials was measured by using AxoGraph 4.5. The action potentials were detected by a fixed amplitude template, which was moved along the recorded traces to test for a match. Data are expressed as mean \pm SEM; $t$ test, ANOVA, and Kolmogorov-Smirnov statistical tests were used. Five concentrations of $\mathrm{NE}(1,3,10,30$, and $100 \mu \mathrm{M})$ were used to test the dose-response of NE. To estimate the $\mathrm{IC}_{50}$ value and maximal response, concentration-response curves were fitted with a least square regression using a logistic equation: $y=a+b /[1+\exp [(x+$ $c) / d]$ ], where $y$ is the magnitude of effect, $a$ is maximum effect, $x$ is drug concentration, and $c$ is the concentration that inhibits the effects by $50 \%$; $b$ and $d$ are constants.

The bath ACSF solution consisted of (in mM) $124 \mathrm{NaCl}, 3 \mathrm{KCl}, 2$ $\mathrm{CaCl}_{2}, 2 \mathrm{MgCl}_{2}, 1.23 \mathrm{NaH}_{2} \mathrm{PO}_{4}, 26 \mathrm{NaHCO}_{2}$, and 10 glucose, $\mathrm{pH}$ 7.4, with $\mathrm{NaOH}$ and was continuously bubbled with $5 \% \mathrm{CO}_{2}$ and $95 \% \mathrm{O}_{2}$. The pipette solution used for most experiments contained (in $\mathrm{mM}$ ) 145 $\mathrm{KMeSO}_{4}$ ( $\mathrm{KCl}$ when recording IPSC), $1 \mathrm{MgCl}_{2}, 10$ HEPES, 1.1 EGTA, 2 Mg-ATP, and $0.5 \mathrm{Na}_{2}$-GTP, pH 7.3, with $\mathrm{KOH}$.

In experiments on calcium currents, the recorded neuron was clamped at $-80 \mathrm{mV}$ and then given a voltage step to $0 \mathrm{mV}$. During these experi-
C. Non-hypocretin cell-NE inhibition

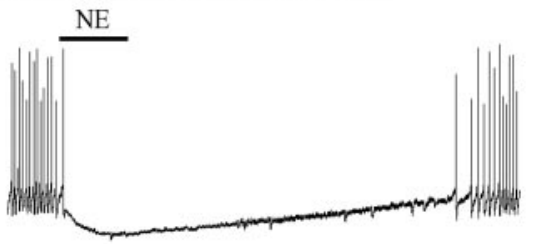

D. Silent non-hypocretin cell-NE hyperpolarization

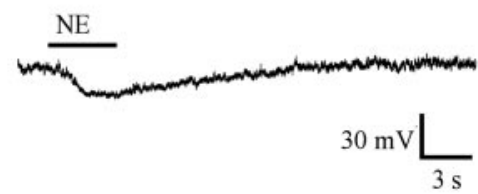

$30 \mathrm{mV} \underset{3 \mathrm{~s}}{\bigsqcup}$
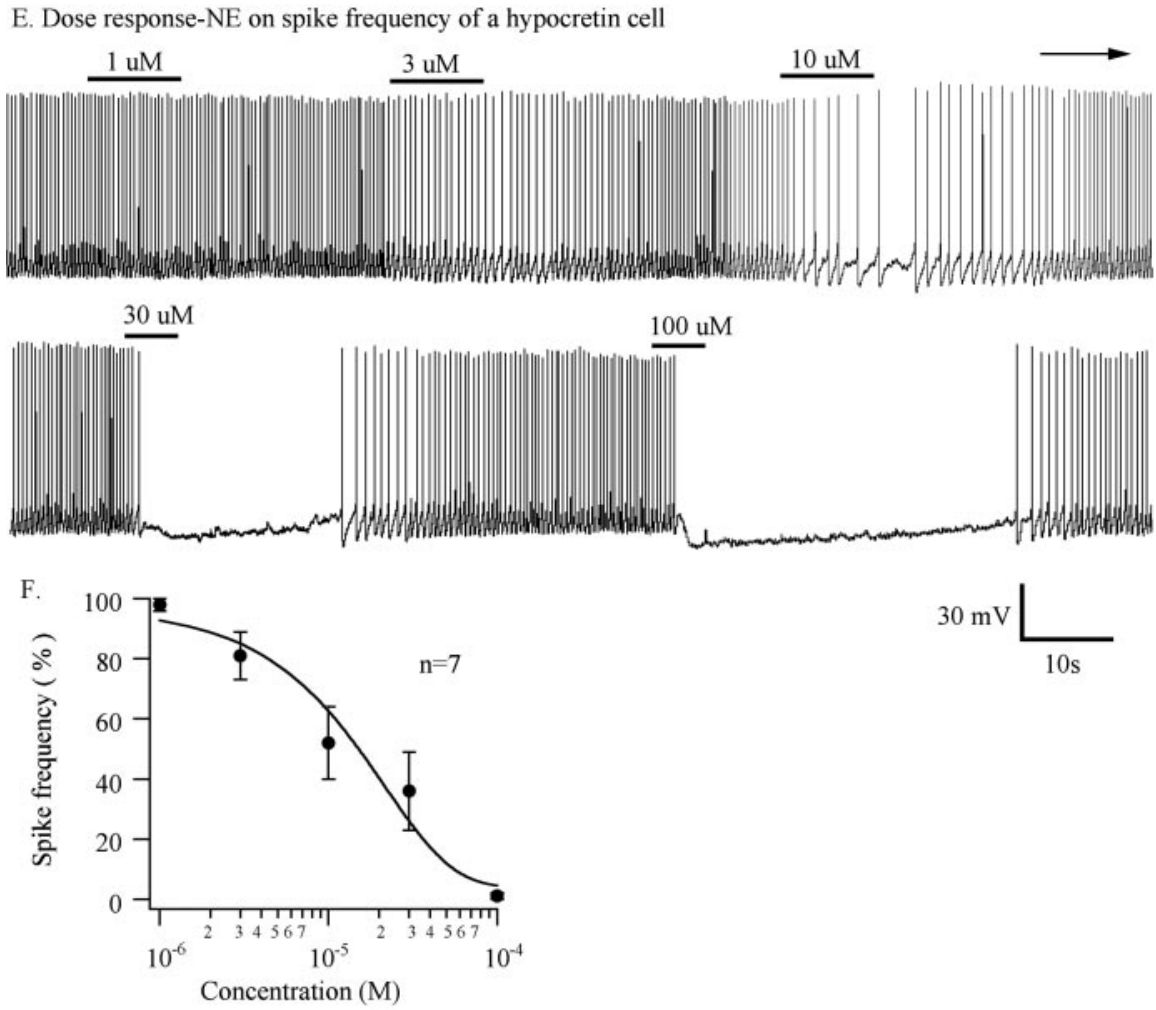

Figure 1. Inhibitory responses of hypocretin cells and nonhypocretin cells to NE. $A, A$ typical and consistent response of a hypocretin cell to NE (50 $\mu \mathrm{m}$ ) during current clamp. B, Some non-GFP control cells showed no response to NE. C, Other non-GFP control neurons (13 of 17 tested) showed an inhibitory response to NE. D, Silent non-GFP cell was hyperpolarized by NE (2 of 17 cells). Drug applications are indicated with horizontal bars. E, A typical hypocretin cell showed a dose-dependent inhibition by NE. $F$, Dose-response curve for the effect of NE on spike frequency $(n=7)$.

ments, the bath solution contained (in mM) $100 \mathrm{NaCl}, 40$ TEA-Cl, 2.5 $\mathrm{KCl}, 5 \mathrm{BaCl}_{2}, 10 \mathrm{HEPES}, 10$ glucose, and $1 \mu \mathrm{M}$ TTX, $\mathrm{pH}$ adjusted to 7.3 with $\mathrm{KOH}$. The pipette solution contained (in $\mathrm{mM}$ ) $135 \mathrm{CsCl}, 1 \mathrm{MgCl}_{2}, 10$ HEPES, 5 BAPTA-Cs, $4 \mathrm{Mg}$-ATP, and $0.5 \mathrm{Na}_{2}$-GTP, pH adjusted to 7.3 with $\mathrm{CsOH}$.

All drugs were given by flow pipette application, unless noted otherwise. Drug solutions were prepared by diluting the appropriate stock solution with ACSF, unless noted otherwise. The following drugs were used: hypocretin-1 (Phoenix Pharmaceuticals, Belmont, CA), hypocretin-2 (Stanford University Peptide Facility, Stanford, CA), TTX (Alomone Labs, Jerusalem, Israel), bicuculline methiodide (BIC), DL-2-amino-5-phosphonovaleric acid (AP-5), 6-cyano-7-nitroquinoxaline-2,3-dione (CNQX), muscimol, norepinephrine bitartrate salt, epinephrine bitartrate salt, dopamine hydrochloride, clonidine hydrochloride, idazoxan hydrochloride, and phenylephrine hydrochloride (Sigma, St. Louis, MO). To protect NE, epi- 
A. $\alpha_{2}$ antagonist blocks NE-induced inhibition of spikes

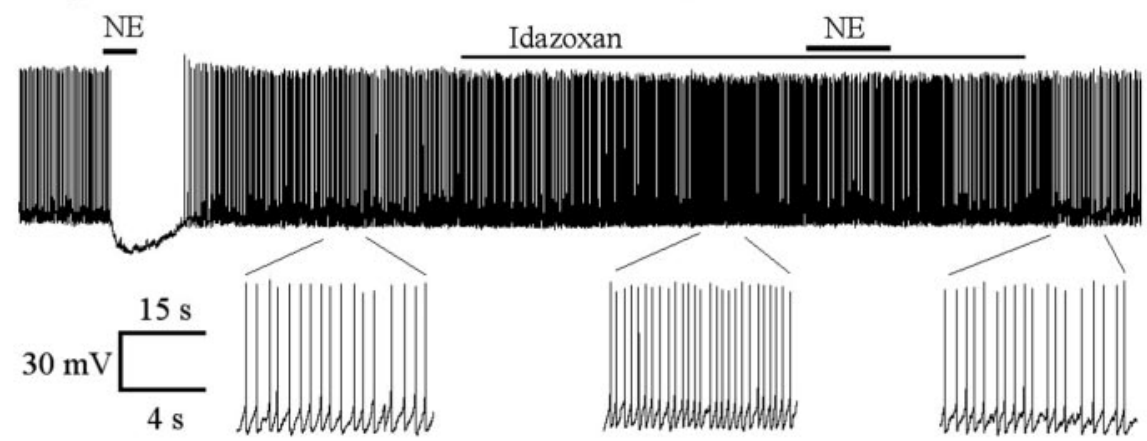

B. $\alpha_{2}$ agonist blocks spikes

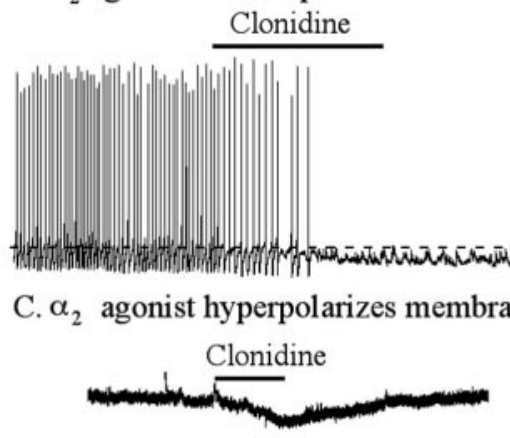

D. $\alpha_{1}$ agonist reduces spike frequency Phenylephrine

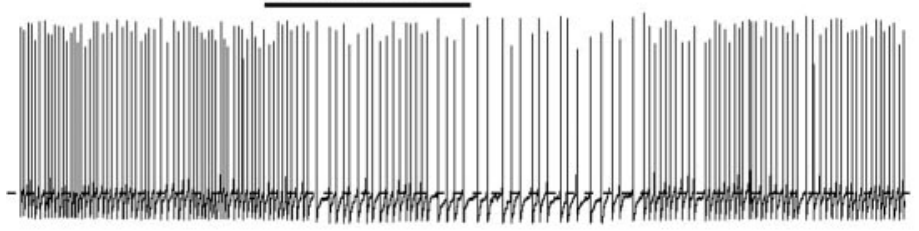

E. $\alpha_{1}$ agonist does not change membrane potential

(in TTX, AP-5, CNQX, BIC)

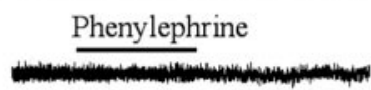

Figure 2. The $\alpha 2$ receptor mediates direct NE-induced inhibition of hypocretin cells. $A$, Top, $\alpha 2$ antagonist idazoxan (10 $\mu \mathrm{m})$ increased spike frequency and blocked NE-induced inhibiton of spikes $(n=7)$. Bottom, Part of extended traces shown above. $B$, The $\alpha 2$ agonist clonidine (100 nm) blocked spikes $(n=5)$. C, Clonidine (100 nm) hyperpolarized the membrane potential in the presence of TTX, AP-5, CNQX, and bicuculline. $D$, The $\alpha 1$ agonist phenylephrine $(25 \mu \mathrm{m})$ reduces spike frequency $(n=6) . E_{i}$ Phenylephrine (50 $\mu \mathrm{m})$ did not change the membrane potential in the presence of TTX (0.5 $\mu \mathrm{M}), \operatorname{AP}-5(50 \mu \mathrm{M}), \operatorname{CNQX}(10 \mu \mathrm{M})$, and bicuculline $(30 \mu \mathrm{m})$.

nephrine, and dopamine from degradation, all buffers used in an experiment included the antioxidant sodium metabisulfite $(10 \mu \mathrm{M})$, and solutions were prepared freshly before the experiment and protected from bright light.

\section{Results}

Norepinephrine blocks spikes and hyperpolarizes membrane potential

Hypocretin neurons, identified by selective GFP expression (Li et al., 2002; Yamanaka et al., 2003b), were studied in hypothalamic slices from transgenic mice in voltage and current clamp. We first tested the effect of NE $(50 \mu \mathrm{M})$ in current clamp. Most GFPexpressing hypocretin neurons showed spontaneous spikes with a frequency of $\sim 2-4 \mathrm{~Hz}$. All hypocretin neurons tested $(n=21)$ showed a consistent reduction or block of spikes and hyperpolar- ization by $9.8 \pm 1.4 \mathrm{mV}$ (range, $4-16 \mathrm{mV}$; $p<0.05$; ANOVA) in response to $\mathrm{NE}$ $(50 \mu \mathrm{M})$.

To investigate whether non-GFP cells respond to NE similar to the responses of hypocretin cells in current clamp, 17 nonGFP cells were tested. Four of these 17 control cells $(23.5 \%)$ showed no response to $50 \mu \mathrm{M} \mathrm{NE}$, as shown in the example in Figure $1 B$; two control cells were silent and showed no spikes. In 11 of 17 control cells (64.7\%), NE (50 $\mu \mathrm{M})$ blocked spike frequency and hyperpolarized membrane potential (Fig. $1 C$ ), similar to the response of hypocretin neurons (Fig. 1A). Two of 17 cells that showed no spontaneous spikes also demonstrated a NE-mediated hyperpolarization (Fig. $1 \mathrm{D}$ ). In these non-green control neurons, NE application hyperpolarized the membrane potential by $9 \pm 1.3$ $\mathrm{mV}$ (range, $6-16 \mathrm{mV} ; p<0.05$; ANOVA; $n=11)$.

In hypocretin neurons, the inhibitory effect of NE on spike frequency was dependent on the concentration of NE applied. The neurons were tested with brief application of $1,3,10,30$, and $100 \mu \mathrm{M}$ NE under current clamp. A dose-response curve for the spike frequency produced by NE showed a greater reduction in spike frequency as concentration increased and revealed an $\mathrm{IC}_{50}$ value of $15 \mu \mathrm{M}(n=7)$ (Fig. $\left.1 F\right)$. Figure $1 E$ shows a typical neuron response to five different concentrations of NE.

\section{Receptor type}

To determine the adrenoceptor subtypes that mediate the inhibition induced by NE in hypocretin cells, we first examined the actions of a selective $\alpha 2$ adrenoceptor antagonist on the spike frequency under current clamp. Application of $50 \mu \mathrm{M} \mathrm{NE}$ alone blocked spike frequency; spike frequency returned to the control level after washout (Fig. 2A). Then, the neuron was pretreated with the $\alpha 2$ receptor antagonist idazoxan. In the presence of idazoxan, NE failed to reduce the spike frequency. Furthermore, even in the absence of added NE, idazoxan increased spike frequency by $15.4 \pm 3.8 \%(n=10$; $p<0.05$; ANOVA) (Fig. $2 A$ ), suggesting that the hypocretin neurons may be under ongoing inhibition by endogenous $\alpha 2$ receptor agonists. Next, we tried the selective $\alpha 2$ adrenoceptor agonist clonidine. Clonidine (100 nM) reduced spike frequency and hyperpolarized the membrane potential $(4.6 \pm 0.7 \mathrm{mV}$; range, $3-7$ $\mathrm{mV} ; n=5$; $p<0.05$; ANOVA) (Fig. $2 B$ ). When the neuron was pretreated with TTX $(0.5 \mu \mathrm{M})$, AP-5 $(50 \mu \mathrm{M})$, CNQX $(10 \mu \mathrm{M})$, and bicuculline $(30 \mu \mathrm{M})$, clonidine $(100 \mathrm{nM})$ also hyperpolarized the membrane potential $(4.1 \pm 0.5 \mathrm{mV}$; range, $3-6 \mathrm{mV} ; n=5$; $p<0.05$; ANOVA) (Fig. 2C). Together, these data suggest that the $\alpha 2$ adrenoceptor subtype mediates the direct inhibition caused by NE.

To determine which other receptor types mediate inhibition 
in addition to the $\alpha 2$ receptor, we also studied the effect of the specific $\alpha 1$ adrenoceptor agonist phenylephrine on spike frequency under current clamp. Phenylephrine $(25 \mu \mathrm{M})$ decreased spike frequency by $30.3 \pm 8.4 \%(n=6 ; p<0.05$; ANOVA) (Fig. 2D). Spike frequency returned to the control level after washout of phenylephrine. The membrane potential was not changed by phenylephrine $(p>$ 0.05 ; ANOVA; $n=6)$. In the presence of TTX $(0.5 \mu \mathrm{M})$, AP-5 (50 $\mu \mathrm{M})$, CNQX (10 $\mu \mathrm{M})$, and bicuculline $(30 \mu \mathrm{M})$, phenylephrine $(50 \mu \mathrm{M})$ exerted no effect on the membrane potential $(n=6$; ANOVA; $p>$ 0.05 ) (Fig. $2 E$ ), supporting the view that the $\alpha 1$-mediated inhibition of hypocretin cells was based on indirect mechanisms.

To study $\beta$ receptors, hypocretin neurons were pretreated with the $\beta$ receptor antagonist propranolol $(20 \mu \mathrm{M})$ for $2 \mathrm{~min}$; this caused a small statistically insignificant reduction in spike frequency (11.2 \pm $6.8 \%$ decrease; $n=7$; ANOVA; $p>0.05)$. In the presence of propranolol, NE $(20$ $\mu \mathrm{M})$ still eliminated spikes and hyperpolarized the membrane potential by $8.0 \pm$ $1.2 \mathrm{mV}$ (Fig. 3A); after washout, spike frequency and membrane potential returned to the control level. Subsequently, when NE was applied in the absence of propranolol, spikes were blocked, and membrane potential was hyperpolarized to a similar level of $8.5 \pm 1.2 \mathrm{mV}$. In TTX $(0.5 \mu \mathrm{M}), \mathrm{NE}(20 \mu \mathrm{M})$ hyperpolarized the membrane potential by $9.8 \pm 1.4 \mathrm{mV}$ (Fig. $3 B$ ), and after washout, the membrane potential returned to the control level. In the presence of propranolol $(20 \mu \mathrm{M})$, NE still hyperpolarized the membrane potential by $9.2 \mathrm{mV} \pm 1.6 \mathrm{mV}(n=7)$. There was no significant difference between NE alone and NE plus propranolol relative to hyperpolarization of the membrane potential $(n=7$; ANOVA; $p>0.05)$.

To further study possible $\beta$ receptor involvement, we used the specific $\beta$ receptor agonist isoproterenol. Isoproterenol $(50 \mu \mathrm{M})$ had no effect on spike frequency ( $3 \pm 4.3 \%$ rise) (Fig. $3 C$ ) or membrane potential $(-1 \pm 1.3 \mathrm{mV} ; n=6$; ANOVA; $p>0.05)$. These data suggest that NE-induced inhibition of hypocretin neurons was not mediated by $\beta$ receptor.

\section{NE-induced GIRK current}

In other brain regions (e.g., the LC and the superior cervical ganglion neurons) (Jeong and Ikeda, 1998; Ishimatsu et al., 2002), NE-mediated inhibition can be based on the activation of a G-protein inward rectifying $\mathrm{K}^{+}$(GIRK) current. We tested the hypothesis that NE activates a GIRK current in hypocretin cells. AP-5 (50 $\mu \mathrm{M})$, CNQX (10 $\mu \mathrm{M})$, BIC $(30 \mu \mathrm{M})$, and TTX $(0.5 \mu \mathrm{M})$ were used to block synaptic activity in this experiment. Currentvoltage curves were obtained using a voltage ramp from -170 to $-30 \mathrm{mV}$. When the concentration of extracellular $\mathrm{K}^{+}$was $16 \mathrm{mM}$ (145 $\mathrm{mm}$ intracellular $\mathrm{K}^{+}$), the NE-induced current reversed at $-56 \mathrm{mV}$ and was strongly inwardly rectifying (Fig. $4 \mathrm{Al}$ ), with an inward current at $-130 \mathrm{mV}$, at least four times greater than the outward current at $-40 \mathrm{mV}$ (Fig. 4A2). The $\alpha 2$ adrenoceptor antagonist idazoxan blocked the NE-induced current (Fig. $4 A 1, A 2)(n=4)$. With the same voltage ramp from -170 to -30 $\mathrm{mV}$, the specific $\alpha 2$ agonist clonidine (200 nM) mimicked the
NE-induced GIRK-type current $(n=6)$. In contrast, the $\alpha 1$ agonist phenylephrine $(25 \mu \mathrm{M})$ showed little effect $(n=6)$. This suggests that the NE-induced inwardly rectified current is mediated by the $\alpha 2$ adrenoceptor.

Previous reports have suggested that the inwardly rectifying potassium current can be blocked with external barium (Takigawa and Alzheimer, 1999). A concentration of $2 \mathrm{mM}$ external Ba ${ }^{2+}$ blocked the inward current induced by NE (Fig. $4 B 1, B 2)(n=4)$.

Figure 4, $C$ and $D$, shows the dependence of the NE-activated current on external $\mathrm{K}^{+}$concentration in a typical neuron. As $\mathrm{K}^{+}$ was increased from 6 to $16 \mathrm{~mm}$, the inward current increased dramatically, and the reversal potential shifted as predicted by the Nernst equation for a $\mathrm{K}^{+}$-selective conductance (Fig. 4C1,C2) $(n=$ 6). Figure $4 D$ shows individual current responses obtained before and during NE application at the indicated voltage steps. When the membrane potential was depolarized to $+20 \mathrm{mV}$, NE induced an outward current; when the membrane potential was hyperpolarized to $-130 \mathrm{mV}$, NE induced an inward current $(n=4)$. These data suggest that $\mathrm{NE}$ induces an inwardly rectifying $\mathrm{K}^{+}$current.

GTP- $\gamma-\mathrm{S}$ is a nonhydrolyzable GTP analog that can activate G-proteins irreversibly. We tested the effect of NE on inwardly rectified current when GTP- $\gamma$-S was used in the pipette solution. After whole-cell configuration was achieved, NE could still evoke an inward rectified current for a short time $(<3 \mathrm{~min})$. However, as the GTP- $\gamma$-S diffused out of the pipette and into the neuron, $\mathrm{NE}$ failed to induce an inward-rectified current. Figure $4 E 1$ plots the diminishing effect of NE as GTP- $\gamma$-S diffuses into the recorded cell. A second application of NE produced a significantly smaller effect than the first application applied before the GTP analog diffused into the cell ( $p<0.05$; ANOVA; $n=6)$ (Fig. $4 E 2)$. These data suggest that NE-induced $\mathrm{K}^{+}$current is G-protein dependent.

\section{$\alpha 1$ Receptor involved in NE-induced enhancement of inhibitory synaptic activity}

To determine whether $\alpha 1$ or $\alpha 2$ adrenoceptors are involved in the NE-induced inhibition of spike frequency through changing syn- 
Idazoxan and $\mathrm{Ba}^{2+}$ block NE-induced GIRK current
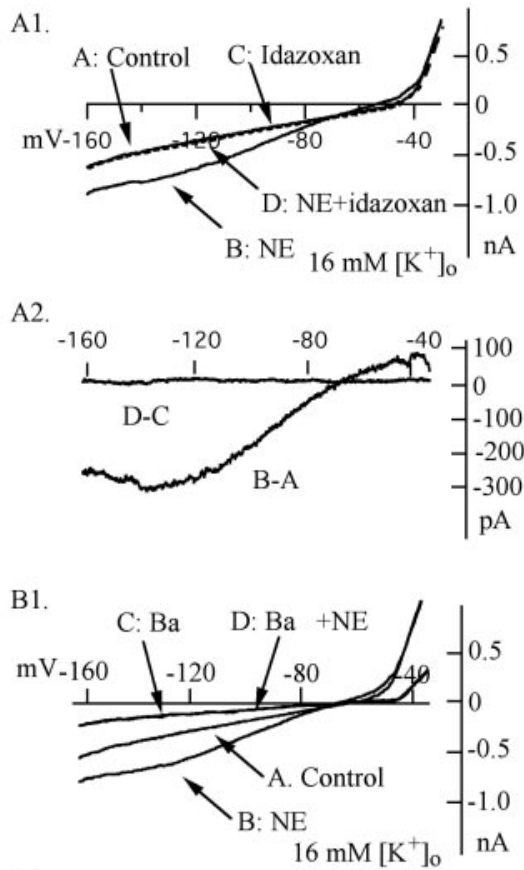

B2.

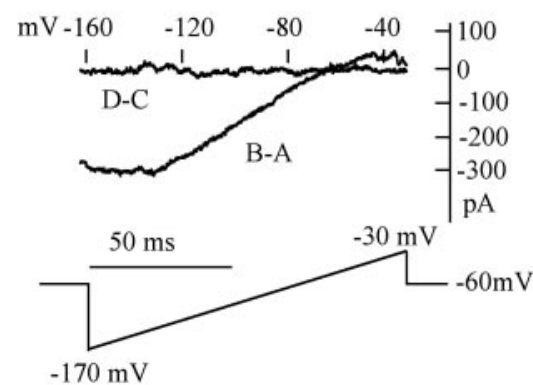

$\mathrm{C} 1$
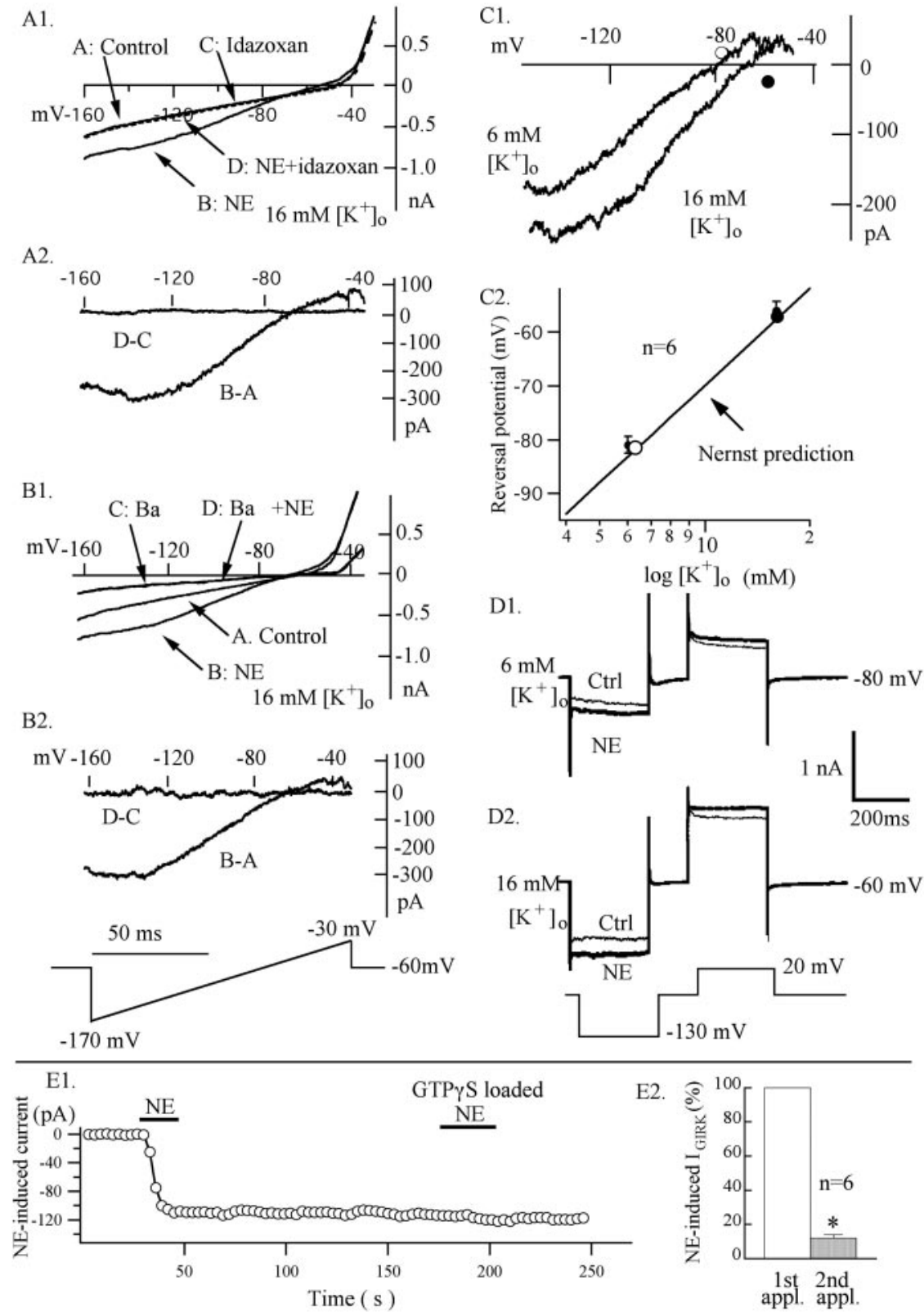

Figure 4. GIRK current activated by an $\alpha 2$ receptor. The $\alpha 2$ antagonist idazoxan (10 $\mu \mathrm{m})$ blocked an NE-induced GIRK-type current. AP-5 $(50 \mu \mathrm{M})$, CNQX $(10 \mu \mathrm{M}), \mathrm{BIC}(30 \mu \mathrm{M})$, and TTX $(0.5 \mu \mathrm{M})$ were used to block synaptic activity in this experiment. A1, Current was measured in the absence and in the presence of NE $(50 \mu \mathrm{m})$ with and without idazoxan at voltages from -170 to $-30 \mathrm{mV}$, varied by a voltage ramp lasting $100 \mathrm{msec}$. Current traces are signal averaged from four traces for control, NE, idazoxan, and NE plus idazoxan, respectively. $A 2$, NE-induced current $(B-A)$ was obtained by subtraction of the trace $A$ from trace $B$; trace $D-C$ was obtained by subtraction of the trace ( from trace D. $B, B^{2+}$ blocked NE-induced GIRK-type current. B1, Current was measured in the absence and the presence of NE $(50 \mu \mathrm{m})$ with and without $\mathrm{Ba}^{2+}$. Current traces are signal averaged from four traces for control, $\mathrm{NE}, \mathrm{Ba}^{2+}$, and NE plus $\mathrm{Ba}^{2+}$, respectively. $\mathrm{B2}, \mathrm{NE}$-induced current (B-A) was obtained by subtraction of the trace $A$ from trace $B$; trace $D-C$ was obtained by subtraction of the trace $C$ from trace $D$. $C 1$, Dependence on external $\mathrm{K}^{+}$. Current-voltage relationships for the NE-induced current with 6 and $16 \mathrm{~mm}$ external $\mathrm{K}^{+}$are shown. Each trace is the difference between current in $\mathrm{NE}(50 \mu \mathrm{m})$ and control current (signal-averaged $1 \mathrm{NE}$ and 1 control trace from each of 6 neurons). C2, Reversal potential as a function of external $\mathrm{K}^{+}$. Reversal potentials for NE-induced current are $-81 \mathrm{mV}$ with $6 \mathrm{~mm} \mathrm{~K}^{+}$and $-56 \mathrm{mV}$ with $16 \mathrm{~mm} \mathrm{~K}^{+}$. The solid line is the Nernst potassium equilibrium potential $(\mathrm{RT} / \mathrm{F})^{*} \mathrm{I}\left(\left[\mathrm{K}^{+}\right]_{0} /\left[\mathrm{K}^{+}\right]_{\mathrm{i}}\right)$, with $\left[\mathrm{K}^{+}\right]_{\mathrm{i}}=145 \mathrm{~mm}$ and $\mathrm{T}=30^{\circ} \mathrm{C}$. Bath solution had an equimolar substitution of $\mathrm{KCl}$ for $\mathrm{NaCl}$ to obtain the desired $\mathrm{KCl}$ concentration. $\mathrm{D}$, NE induced outward current at $+20 \mathrm{mV}$ and inward current at $-130 \mathrm{mV}$ under voltage clamp. When external $\left[\mathrm{K}^{+}\right]$was $6 \mathrm{~mm}$, the membrane potential was held at $-80 \mathrm{mV}$; when external $\left[\mathrm{K}^{+}\right]$was $16 \mathrm{~mm}$, the membrane potential was held at $-60 \mathrm{mV}$. E, NE initially induced an inwardly rectified $\mathrm{K}^{+}$current with GTP- $\gamma$-S loaded in the pipette. E1, A typical neuron showing that the NE-induced inward current did not recover when the cell was loaded with GTP- $\gamma$-S. NE failed to induce the inward current when applied several minutes after cell dialysis. E2, A bar graph illustrates that the response to a second application of NE is significantly reduced $(p<0.05)$. Asterisks indicate significant statistical differences by ANOVA $(p<0.05)$. aptic activity, we tested clonidine and phenylephrine on IPSCs and EPSCs. The glutamate antagonists AP-5 $(50 \mu \mathrm{M})$ and CNQX $(10 \mu \mathrm{M})$ were used to block EPSCs and record IPSCs. Bicuculline ( $30 \mu \mathrm{M})$ was used to block IPSCs to record selectively EPSCs. Clonidine (100 nM) had little effect on the frequency or amplitude of IPSCs or EPSCs. After clonidine was applied, the frequency of EPSCs was $115 \pm 21 \%$ of control $(n=5 ; p>0.05$; ANOVA) and then returned to $110 \pm 4.5 \%$ after washout. Similarly, phenylephrine did not significantly change the frequency or the amplitude of EPSCs $(n=5 ; p>0.05$; ANOVA for frequency and KolmogorovSmirnov for amplitude). In phenylephrine, the frequency of EPSCs was $127 \pm$ $19 \%$ of controls $(n=5 ; p>0.05$; ANOVA) and then returned to $113 \pm 18 \%$ after washout.

Phenylephrine $(25 \mu \mathrm{M})$ increased the frequency and amplitude of IPSCs (Fig. $5 A$ ). The frequency of IPSCs increased to $469 \pm 249 \%$ (range, $107-1450 \% ; n=6$; $p<0.05$; ANOVA) (Fig. $5 B$ ) when phenylephrine was applied, then returned to $125 \pm 32 \%$ after washout. Figure $5 C$ shows a typical neuron cumulative probability before and during phenylephrine. Phenylephrine increased the amplitude of IPSCs (Kolmogorov-Smirnov test; $p<0.05 ; n=$ $5)$. The mean amplitude in controls was $16.5 \pm 0.6 \mathrm{pA}$, and this increased to $38.2 \pm$ $1.1 \mathrm{pA}$ in phenyephrine and then returned to $22.9 \pm 0.5 \mathrm{pA}$ during washout.

To determine whether the phenylephrine-induced increase in IPSCs was mediated by presynaptic or postsynaptic actions, we examined miniature IPSCs (mIPSCs) in the presence of TTX $(0.5 \mu \mathrm{M})$ and glutamate receptor antagonists $\mathrm{AP}-5(50 \mu \mathrm{M})$ and CNQX $(10 \mu \mathrm{M})$. Phenylephrine $(25 \mu \mathrm{M})$ increased the frequency of mIPSCs to $253.7 \pm$ $58.5 \%$ of the control level $(n=6 ; p<0.05$; ANOVA) (Fig. 5E), returning to $167.5 \pm$ $56.0 \%$ after washout. Three cells that showed an increased frequency (mean, $277.3 \pm$ $123 \%$ ) also had an increase in amplitude of mIPSCs in phenylephrine (KolmogorovSmirnov test; $p<0.05 ; n=3$ ) (Fig. $5 F$ ). The other three cells that also showed an increase in mIPSC frequency (mean, $189.2 \pm 36.8 \%$ ) showed no change in amplitude in phenylephrine (Fig. 5G) (Kolmogorov-Smirnov test; $p>0.05 ; n=3)$. Figure $5 D$ shows an example of a neuron before, during, and after phenylephrine. These data showing that some cells show an increase in mIPSC frequency without a change in amplitude suggest that phenylephrine may enhance GABA release by a presynaptic mechanism; in addition, phenylephrine may also increase IPSCs 
$\alpha_{1}$ agonist increases the frequency of IPSCs

A.

(in AP-5 and CNQX)

Control
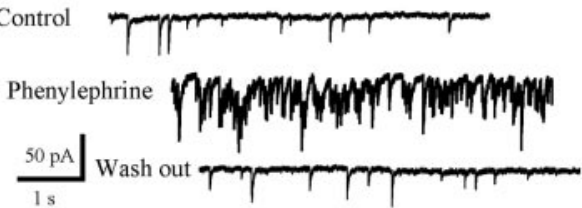

B.

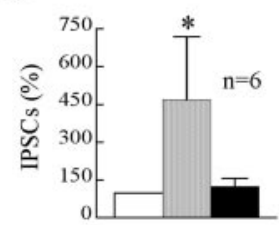

Ctrl PE W/O
C.

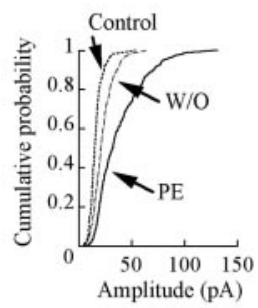

$\alpha_{1}$ agonist increases the frequency of mIPSCs

D.

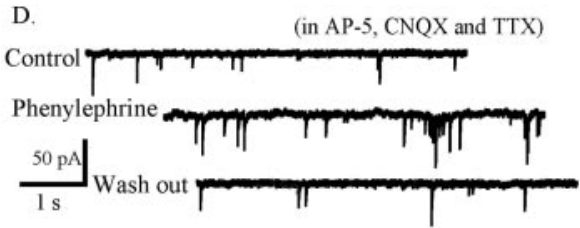

E

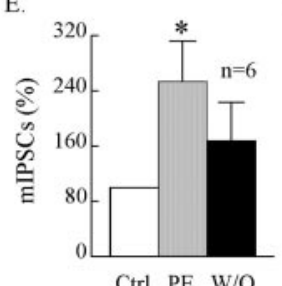

\section{F.}
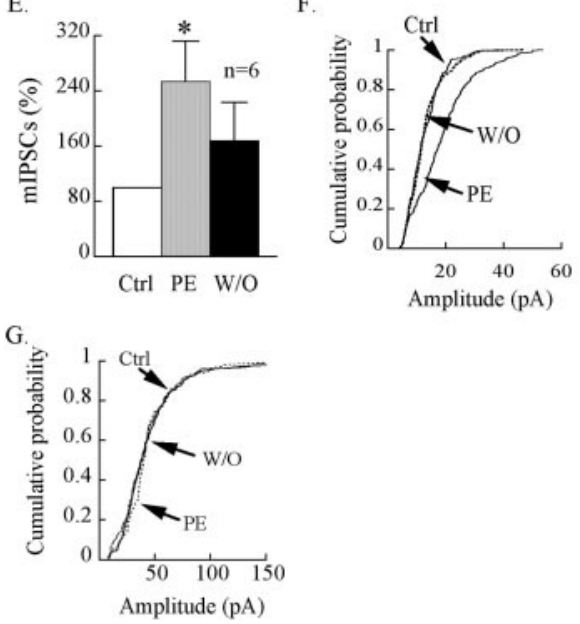

Figure 5. The $\alpha 1$ receptor increases GABA-mediated synaptic tone. The $\alpha 1$ agonist phenylephrine (PE; $25 \mu \mathrm{M}$ ) increased IPSC and mIPSC frequency. Equimolar $\mathrm{KCl}$ was used in the pipette solution instead of $\mathrm{KMeSO}_{4}$ when IPSCs were recorded. AP-5 (50 $\left.\mu \mathrm{M}\right)$ and $\mathrm{CNQX}(10 \mu \mathrm{M})$ were used here to block excitatory synaptic activity. $A$, An example of IPSCs of hypocrein neurons before, during, and after phenylephrine application $(25 \mu \mathrm{M})$. B, Bar graph showing the effect of phenylephrine on the mean frequency of spontaneous IPSCS. C, Cumulative probability plot of the amplitude of IPSCs for the cell shown in $A$. Phenylephrine shifted significantly the amplitude distribution to the right, showing an increase in the amplitude of IPSCs by phenylephrine. D, A typical neuron showing mIPSCs before, during, and after application of the specific $\alpha 1$ agonist phenylephrine $(25 \mu \mathrm{M})$. E, Bar graph showing that the $\alpha 1$ agonist phenylephrine increased the frequency of mIPSCS. F, An example in which phenylephrine increases frequency and amplitude of mIPSCs. G, Phenylephrine in this cell increases the frequency but not the amplitude of $\mathrm{mIPSCs}$. W/O, Washout; Ctrl, control; PE, phenylephrine.

by a postsynaptic effect, as suggested by the change in amplitude in some cells.

NE, phenylephrine, and clonidine decrease $\mathrm{Ca}^{2+}$ current We tested the effect of NE, phenylephrine, and clonidine on $\mathrm{Ca}^{2+}$ currents under whole-cell voltage clamp. AP-5 (50 $\mu \mathrm{M})$, CNQX $(10 \mu \mathrm{M})$, bicuculline $(30 \mu \mathrm{M})$, and TTX $(0.5 \mu \mathrm{M})$ were used to block synaptic activity. $\mathrm{BaCl}_{2}$ was substituted for $\mathrm{CaCl}_{2}$ in the bath solution to increase the conductance at the calcium channel. $\mathrm{Ba}^{2+}$ currents were evoked by steps from a holding potential of -80 to $0 \mathrm{mV}$ for $100 \mathrm{msec}$ at $3 \mathrm{sec}$ intervals (Fig. 6). Inward currents were completely blocked by the $\mathrm{Ca}^{2+}$ channel blocker $\mathrm{Cd}^{2+}(200 \mu \mathrm{M})$ (data not shown). The amplitude of sustained $\mathrm{Ba}^{2+}$ current was $814.4 \pm 173.4 \mathrm{pA}(n=6)$ under these conditions. NE $(50 \mu \mathrm{M})$ decreased the $\mathrm{Ba}^{2+}$ current by $32 \pm 4.1 \%(p<$ 0.05 ; ANOVA), which returned to $93 \pm 2.6 \%$ after washout. Phenylephrine $(50 \mu \mathrm{M})$ decreased the $\mathrm{Ba}^{2+}$ current by $52.7 \pm$ $2.2 \%(p<0.05$; ANOVA; $n=5)$, which returned to $85 \pm 5.4 \%$ after washout. Clonidine decreased the $\mathrm{Ba}^{2+}$ current by $39 \pm$ $2.5 \%(p<0.05$; ANOVA; $n=5)$, returning to $92 \pm 6.4 \%$ after washout. These experiments suggest that $\alpha 1$ and $\alpha 2$ receptor subtypes can modulate calcium channel activity in hypocretin cells. Attenuation of calcium currents has been previously reported to be mediated by both $\alpha 1$ and $\alpha 2$ receptors in cultured rat median preoptic neurons and hippocampal slices (Kolaj and Renaud, 2001; Calcagnotto and Baraban, 2003).

\section{NE-induced response is independent of age}

To determine whether there is a different response to NE between young and mature mice, postnatal day 11 (P11) mice and P64 mice were compared. NE $(50 \mu \mathrm{M})$ was applied directly to the slice by a flow pipette and blocked spike frequency of neurons of P11 mice $(n=6)$ and P64 mice $(n=8)$. The resting membrane potential of P11 mice was $-61 \pm 2 \mathrm{mV}$. NE $(50 \mu \mathrm{M})$ hyperpolarized the membrane potential to $-72 \pm 2 \mathrm{mV}$, which recovered after washout to $-60 \pm 2 \mathrm{mV}$. The resting membrane potential of P64 mice was $-63 \pm 1.2 \mathrm{mV}$. NE $(50 \mu \mathrm{M})$ hyperpolarized the membrane potential to $-71 \pm 3 \mathrm{mV}$, which returned to $-62 \pm 4$ $\mathrm{mV}$ after washout. There was no significant difference in the NE-induced inhibition between 11-d-old mice and 64-d-old mice ( $p>0.05$; ANOVA; Newman-Keuls test). To determine whether rapid application by flow pipe was critical, we compared flow pipe to bath application. Bath-applied NE caused hyperpolarization and inhibition of spike frequency $(n=6)$. There was no significantly different effect between bath application and flow pipe application ( $p>0.05$; ANOVA), except for the slower response time to bath application.

To ensure that NE is capable of exciting recorded neurons under the conditions used in our slice experiments, the effect of $50 \mu \mathrm{M}$ NE on supraoptic nucleus magnocellular neurons was tested. NE has previously been shown to excite neurons of the supraoptic nucleus (Armstrong et al., 1986; Boudaba et al., 2003). In contrast to hypocretin cells, supraoptic neurons $(n=3)$ showed consistent increased spike frequency and depolarization induced by NE, as expected. NE increased spike frequency from $1.1 \pm 0.5 \mathrm{~Hz}$ to $5.3 \pm 0.3 \mathrm{~Hz}$, and then spike frequency returned to $1.5 \pm 0.8 \mathrm{~Hz}$ after washout. NE also depolarized the membrane potential by $3.2 \pm 0.3 \mathrm{mV}$. The membrane potential returned to control levels after washout.

\section{Epinephrine and dopamine inhibit hypocretin neurons}

We also examined the responses of hypocretin neurons to two other catecholamines, epinephrine and dopamine. Epinephrine $(50 \mu \mathrm{M})$ blocked spikes (Fig. 7A) under current clamp. Epinephrine hyperpolarized the membrane potential by $9 \pm 1.0 \mathrm{mV}(n=$ $6 ; p<0.05$; ANOVA) in normal bath conditions. In the presence of TTX $(0.5 \mu \mathrm{M})$, epinephrine hyperpolarized the membrane potential by $8 \pm 0.6 \mathrm{mV}(n=6$; $p<0.05$; ANOVA) (Fig. $7 B)$. Similarly, dopamine $(50 \mu \mathrm{M})$ reduced spike frequency (Fig. $7 C$ ) under current clamp. Dopamine hyperpolarized the membrane 

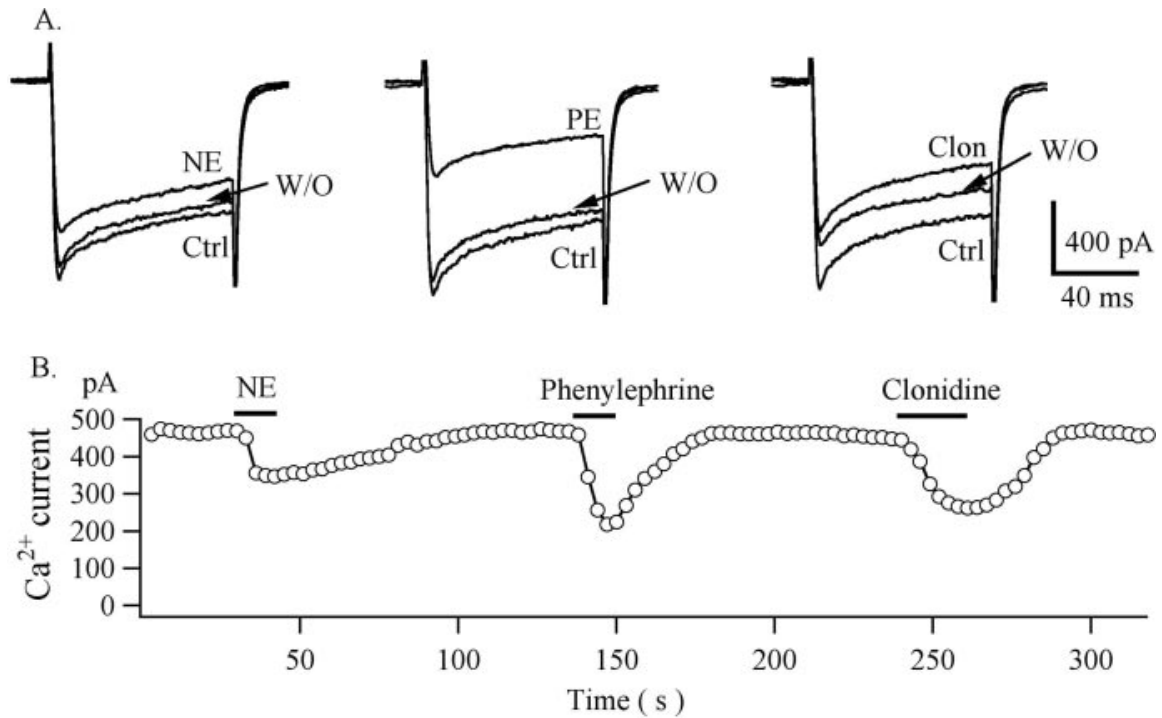

Figure 6. $\mathrm{NE}$, phenylephrine, and clonidine decrease $\mathrm{Ca}^{2+}$ currents. $A$, A single cell responds to $\mathrm{NE}(50 \mu \mathrm{m})$, phenylephrine (50 $\mu \mathrm{M})$, and clonidine $(1 \mu \mathrm{M})$. $B$, Sustained amplitudes of $\mathrm{Ca}^{2+}$ currents were measured during voltage steps from a holding potential of -80 to $0 \mathrm{mV}$ and plotted as a function of time. $\mathrm{NE}$, phenylephrine, and clonidine were applied at the times indicated by horizontal bars. Ctrl, Control; PE, phenylephrine; Clon, clonidine; W/O, washout.

potential by $8.7 \pm 0.7 \mathrm{mV}(n=6 ; p<0.05$; ANOVA $)$ in normal bath solution. In TTX $(0.5 \mu \mathrm{M})$, dopamine hyperpolarized the cells by $7.7 \pm 0.6 \mathrm{mV}(n=6 ; p<0.05$; ANOVA) (Fig. $7 D)$. These data show that both epinephrine and dopamine inhibit hypocretin cells and do so by a direct action in the absence of spikemediated synaptic activity.

Single hypocretin neurons were tested to determine whether one cell would respond to all three catecholamines. Figure $7 E$ shows that spikes were depressed by all three transmitters (NE, epinephrine, and dopamine) applied sequentially to a single neuron. All three catecholamines generated dose-dependent inhibition of hypocretin neurons, with greater inhibition produced by higher doses of the transmitters (Fig. 8). NE (20 $\mu \mathrm{M})$ decreased spike frequency to $20 \pm 9.5 \%$ of control, epinephrine $(20 \mu \mathrm{M})$ decreased spike frequency to $29 \pm 15 \%$ of control, and dopamine $(20 \mu \mathrm{M})$ decreased spike frequency to $53 \pm 17 \%$ of control. Spike frequency recovered to baseline after transmitter washout. There was no significant difference between NE- and epinephrine-mediated, NE- and dopamine-mediated, or between epinephrine- and dopaminemediated inhibition (ANOVA; $p>0.05 ; n=6$ ).

To know which receptor might be involved in dopamineinduced inhibition, we used the dopamine D1/D5 antagonist $R(+)-S C H 23390$ and the D2 antagonist eticlopride in this experiment. Dopamine $(50 \mu \mathrm{M})$ blocked spike frequency and hyperpolarized the membrane potential by $7.1 \pm 0.8 \mathrm{mV}(n=8)$. After washout, spike frequency and membrane potential returned to the control level; when the neuron was pretreated with the D2 antagonist eticlopride $(50 \mu \mathrm{M})$, dopamine did not change the spike frequency or membrane potential (Fig. 9A). In contrast, when the neuron was pretreated with the D1/D5 antagonist $R(+)$-SCH23390 (10 $\mu \mathrm{M})$, dopamine still blocked spike frequency and hyperpolarized the membrane potential by $10 \pm 1.3$ $\mathrm{mV}(n=6)$; after washout, the spike frequency and membrane potential returned to the control level. Then, on the same neuron, dopamine alone blocked spike frequency and hyperpolarized the membrane potential by $9.5 \pm 1.3 \mathrm{mV}$ (Fig. 9B). The D1/D5 antagonist SCH23390 thus had no effect on the dopaminemediated hyperpolarization of membrane potential (ANOVA; $p>0.05)$. These data suggest that the dopamine-induced inhibition of hypocretin neurons was mediated mainly by a D2type receptor and not by a D1/D5 receptor.

\section{Discussion}

Hypocretin neurons play an important role in arousal, and loss of hypocretin or its receptors reduces arousal and can lead to narcolepsy. Similarly, NE has also been shown to enhance arousal. NE exerted profound inhibitory actions on hypocretin neurons by three independent mechanisms. In a dose-dependent manner, NE reduced or blocked spontaneous action potentials. In the absence of spikedependent synaptic input, NE evoked a substantial hyperpolarization of the membrane potential by a mechanism involving activation of a GIRK current through an $\alpha 2$-like receptor. NE reduced calcium currents. NE also exerted an indirect inhibitory effect on hypocretin neurons by increasing the GABA-mediated synaptic activity recorded in hypocretin cells through an $\alpha 1$-like receptor. Hypocretin cells may be under tonic inhibition by NE, because application of the $\alpha 2$ antagonist idazoxan increased spike frequency. Similar to $\mathrm{NE}$, epinephrine and dopamine were also inhibitory to hypocretin neurons.

\section{Mechanisms of NE inhibition of hypocretin neurons}

A primary mechanism of inhibition was dependent on activation of a GIRK-type current. The reversal potential for the current was typical of a $\mathrm{K}^{+}$conductance, and the magnitude of the current was dependent on extracellular $\mathrm{K}^{+}$levels. The current showed inward rectification and was blocked by extracellular barium. That it is G-protein dependent was demonstrated by the block of NE actions when GTP- $\gamma$-S was used to irreversibly activate G-proteins. Together, these characteristics are typical of a GIRK current (Sodickson and Bean, 1996). The NE receptor involved had the characteristics of an $\alpha 2$ receptor, because it could be activated by either NE or the $\alpha 2$ agonist clonidine, and activation of the GIRK current could be blocked by the $\alpha 2$-selective antagonist idazoxan. In contrast, phenylephrine, an $\alpha 1$ agonist, had no effect on the GIRK current. Activation of a GIRK current contributed both to the reduction in spike frequency and to the hyperpolarization of the membrane potential of hypocretin neurons. The $\beta$ receptor agonist isoproteranol had little effect on hypocretin cells, and the $\beta$ receptor antagonist proteranol did not block the actions of NE, suggesting the $\beta$ receptor did not play a prominent role.

NE inhibited $\mathrm{Ca}^{2+}$ conductances, as evaluated with $\mathrm{Ba}^{2+}$ substituted for $\mathrm{Ca}^{2+}$. The $\mathrm{Ba}^{2+}$ conductance could be attenuated both by $\mathrm{NE}$ and clonidine, suggesting involvement of the $\alpha 2$ receptor subtype. In addition, phenylephrine attenuated the $\mathrm{Ba}^{2+}$ current, suggesting that both $\alpha 1$ and $\alpha 2$ receptors may underlie the NE-mediated attenuation of calcium conductances. A NE-mediated depression of $\mathrm{Ca}^{2+}$ could secondarily result in an attenuation of many of the cellular processes in which $\mathrm{Ca}^{2+}$ plays a role as second messenger and, if a parallel mechanism exists in the hypocretin axon terminal, would tend to reduce the probability of transmitter release. 
Interestingly, we identified a third mechanism of inhibition of the hypocretin neurons. NE caused an increase in the bicuculline-sensitive inhibitory synaptic tone. The increase in synaptic inhibition was consistent with activation of a $\alpha 1$ receptor, because it could be emulated by phenylephrine. The finding that mIPSCs could be increased in frequency but not in amplitude in some cells supports the view that $\mathrm{NE}$ can activate an $\alpha 1$ receptor on the terminals of inhibitory neurons that enhances release of GABA onto hypocretin neurons.

Epinephrine and dopamine exerted inhibitory actions that were similar to those found for NE. All three catecholamines reduced spike frequency and hyperpolarized the membrane potential. Epinephrine may act on NE receptors and would therefore probably exert inhibitory effects by mechanisms similar to those delineated for NE (Hoffman and Lefkowitz, 1982). Dopamine acts on its own set of G-protein-coupled receptors. Because the D2 antagonist eticlopride blocked the dopamine-mediated inhibition, but the D1/5 antagonist SCH23390 had no effect, the dopamine D2 receptor is most likely expressed by hypocretin cells and mediates the inhibitory actions of dopamine. Hypocretin neurons send excitatory axons caudally to dopamine- and epinephrine-containing cells, and both epinephrineand dopamine-containing axons have been detected in the lateral hypothalamus (LH) in the area of hypocretin cells (Hokfelt et al., 1984; van den Pol et al., 1984; Astier et al., 1987; Fallon and Ciofi, 1992; Fadel and Deutch, 2002; Korotkova et al., 2002).

\section{Functional importance of NE inhibition of the hypocretin arousal system}

Depending on the receptor subtype expressed, NE has the capacity to either stimulate or depress neuronal activity (Han et al., 2002). For control purposes, we tested the effect of NE on mouse supraoptic nucleus and corroborated previous findings in the rat showing that $\mathrm{NE}$ was excitatory and evoked depolarizing actions (Armstrong et al., 1986; Boudaba et al., 2003). This provides additional support for the specificity of robust inhibitory actions of NE on hypocretin cells in mouse brain slices, in contrast to the excitatory actions on other systems related to arousal such as on the serotonin neurons (Brown et al., 2002). NE and hypocretin axons project to a number of common targets and avoid other regions; NE-immunoreactive axons are found throughout the $\mathrm{LH}$ and surround the hypocretin neurons (Baldo et al., 2003), demonstrating that the anatomical substrate exists for NE cells to modulate hypocretin neurons. NE in a dose-dependent manner consistently depressed the activity of hypocretin cells. This was true of neonatal and adult hypocretin neurons and was found with both a flow pipe aimed at the recorded cell and with bath application of NE.

In contrast to the inhibitory effect of NE on hypocretin neu-

C. Dopamine blocks spikes
A. Epinephrine blocks spike frequency and hyperpolarizes membrane potential Epinephrine
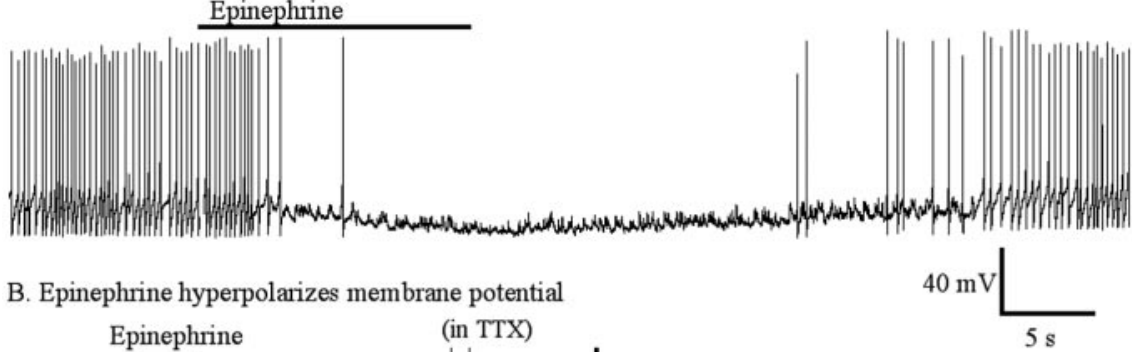

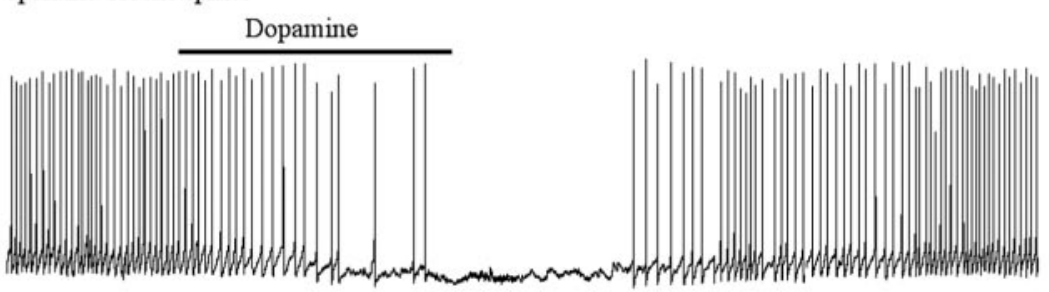

D. Dopamine hyperpolarizes membrane potential

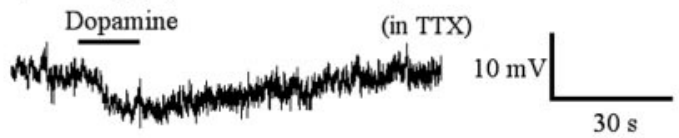

$40 \mathrm{mV}$

E. A single neuron is inhibited by NE, epinephrine and dopamine
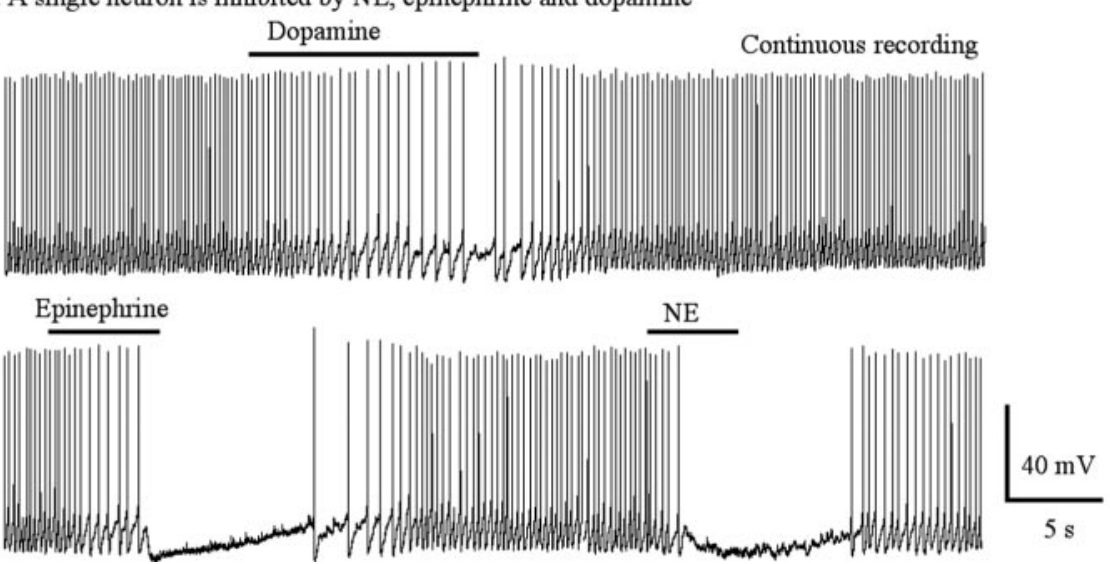

Figure 7. Direct hyperpolarizing actions of epinephrine and dopamine on membrane potential. $A$, Epinephrine $(50 \mu \mathrm{m})$ blocked spike frequency and hyperpolarized membrane potential. $B$, Epinephrine $(50 \mu \mathrm{m})$ hyperpolarized membrane potential in TTX. $C$ Dopamine $(50 \mu \mathrm{m})$ blocked spikes and hyperpolarized membrane potential. D, Dopamine (50 $\mu \mathrm{m})$ hyperpolarized membrane potential in TTX.E, A single neuron responded to NE $(20 \mu \mathrm{m})$, epinephrine (20 $\mu \mathrm{M})$, and dopamine (20 $\mu \mathrm{m})$.

rons, hypocretin exerts a profound excitatory effect on NE neurons primarily by activating the hypocretin receptor 1 of the rat (Hagan et al., 1999; Horvath et al., 1999; Ivanov and Aston-Jones, 2000) and mouse (van den Pol et al., 2002) LC. In parallel, a high density of hypocretin axons is found in the LC (Peyron et al., 1998), where asymmetrical synapses are made by hypocretin axons onto NE neurons (Horvath et al., 1999).

As loss of hypocretin or its receptors can cause narcolepsy; the symptoms of narcolepsy may be relevant to understand the role of hypocretin in arousal. Narcoleptics have no trouble with directed attention or arousal over the short term but have significant problems with sleep-wake regulation over the long term. Whereas the total sleep per $24 \mathrm{hr}$ may not be increased in narcolepsy, narcolepsy produces a syndrome in which the sleep debt 
NE, epinephrine and dopamine decrease spikes and hyperpolarize membrane potential
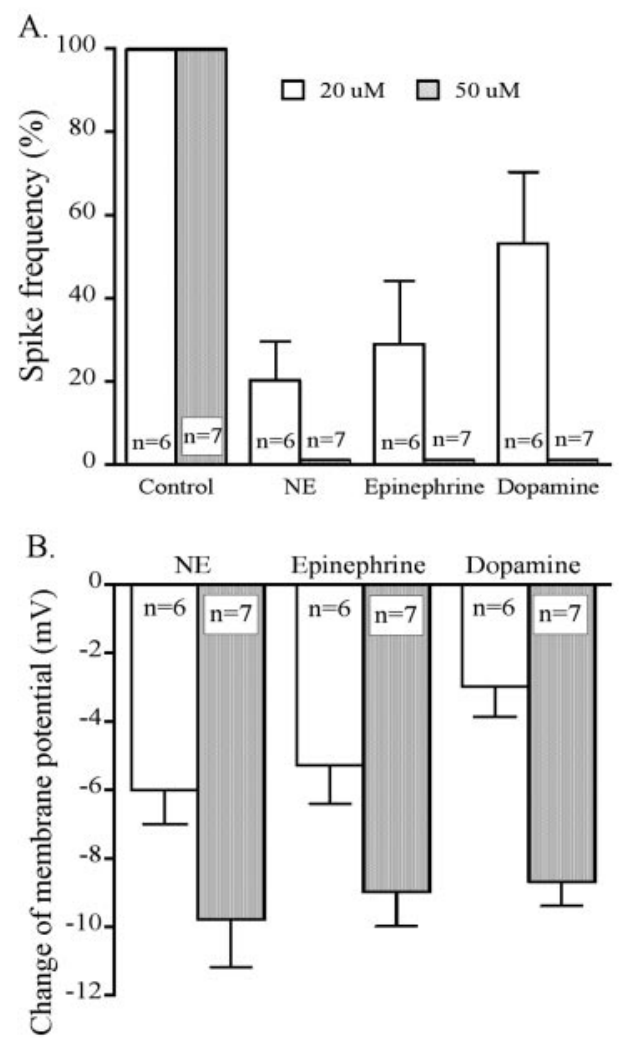

Figure 8. Dose dependence of catecholamine inhibition. The bar graph shows the effect of different concentrations of NE, epinephrine, and dopamine on spike frequency $(A)$ and membrane potential $(B)$.

cannot be delayed until night but must be paid every few hours. Hypocretin neurons may play a role in positive energy balance; CNS application of hypocretin has been reported to increase food intake. The arousal mediated by hypocretin neurons may be modulated by the energy state (Yamanaka et al., 2003b). That the two systems may subserve somewhat different functions is sup-

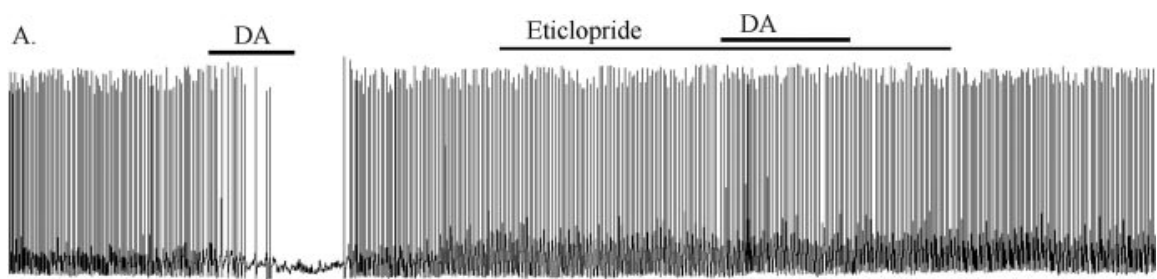

B. DA SCH-23390 DA

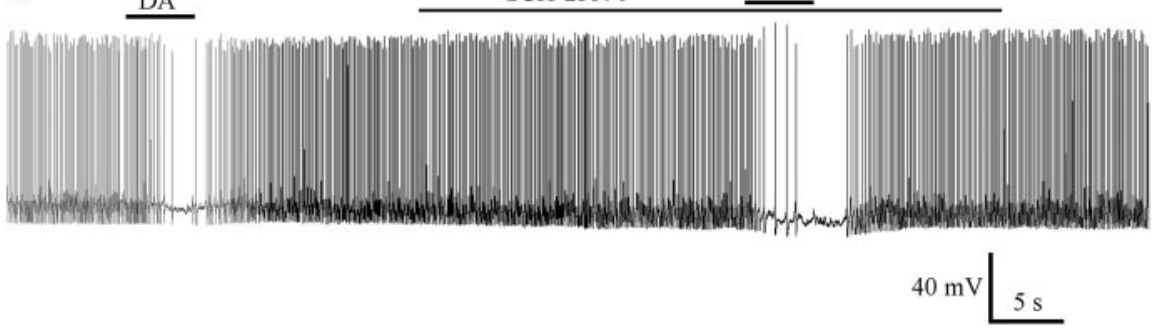

Figure 9. Dopamine-induced inhibition mediated by the $\mathrm{D} 2$ receptor. $A$, The $\mathrm{D} 2$ receptor antagonist epticlopride (50 $\mu \mathrm{m})$ reversibly blocked the dopamine-mediated inhibition. B, The D1/D5 antagonist SCH23390 (10 $\mu \mathrm{m}$ ) had little effect on dopaminemediated inhibition. DA, Dopamine (50 $\mu \mathrm{M})$. ported by analyses of daily rhythms; NE levels are reported to increase at the beginning of the wake period, whereas hypocretin levels increase later in the wake period (Mitome et al., 1994; Mochizuki and Scammell, 2003; Zeitzer et al., 2003), consistent with the view that hypocretin may generally oppose sleepiness during periods of prolonged wakefulness (Yoshida et al., 2001), whereas NE increases rapidly after waking.

One source of NE to the LH may be the LC. Activity of NEreleasing LC neurons correlates with attention and sensory arousal. The synchronized firing rate of LC neurons is positively correlated with cognitive performance (Usher et al., 1999; Rajkowski et al., 2004), possibly mediated by gap junction interneuronal signaling in the LC (Christie et al., 1989). Interestingly, hypocretin enhances the simultaneous firing of LC neurons in slices (van den Pol et al., 2002). NE helps to focus attention on task-relevant behavior by attenuating the influence of distracting stimuli, particularly under conditions of elevated arousal (Robbins, 1984). NE inhibition of hypocretin cells may be part of a negative feedback to inhibit runaway arousal, or to allow a high degree of attention to focus by reducing output of other nonselective arousal-related systems including the hypocretin system. Hypocretin neurons may influence motor control, as suggested by the sleep paralysis and cataplexy found in hypocretin-deficient narcoleptics, by reports of direct activation of motor neurons by hypocretin, and by the reduction in the activity of NE cells during cataplexy; catecholamine feedback inhibition of hypocretin cells may therefore be relevant to the fine-tuning of motor tone (Nishino and Mignot, 1997; Peever et al., 2003; John et al., 2004; Yamuy et al., 2004).

But another possibility is that the NE axons that innervate the hypocretin neurons arise not primarily from the LC but from other NE neurons in the hindbrain, perhaps from A1 or A2, or other axons could arise from adrenergic neurons in $\mathrm{C} 1$ that project to the LH (Mason and Fibiger, 1979; Aston-Jones, 2004). These cells have a different function from the LC neurons and may relate more to control of vegetative and homeostatic processes, potentially linking the enteroceptive cells of the gut with the LH. The A2 cells of the nucleus of the solitary tract project to the LH area, and cells of the nucleus of the solitary tract show excitatory responses to hypocretin (Smith et al., 2002; Yang and Ferguson, 2003). Studies combining tract-tracing with immunostaining have shown a very specific innervation of subregions of the hypothalamic paraventricular nucleus by different catecholamine projections (Sawchenko and Swanson, 1982; Cunningham and Sawchenko, 1988). Similar experiments delineating the origin of NE fibers to hypocretin neurons would be helpful in assessing the functional relevance of NE inhibitory actions on the hypocretin cells.

The multiple direct and indirect mechanisms involved, the fact that hypocretin cells appear to be tonically depressed by $\alpha 2$ receptors under baseline conditions, and the finding that dopamine, epinephrine, and NE have similar attenuating actions underscore the importance of catecholamine inhibition of the hypocretin arousal system.

\section{References}

Alexander JT, Cheung WK, Dietz CB, Leibowitz SF (1993) Meal patterns and macronutrient in- 
take after peripheral and PVN injections of the $\alpha 2$-receptor antagonist idazoxan. Physiol Behav 53:623-630.

Armstrong WE, Gallagher MJ, Sladek CD (1986) Noradrenergic stimulation of supraoptic neuronal activity and vasopressin release in vitro: mediation by an $\alpha 1$-receptor. Brain Res 365:192-197.

Astier B, Kitahama K, Denoroy L, Jouvet M, Renaud B (1987) Immunohistochemical evidence for the adrenergic medullary longitudinal bundle as a major ascending pathway to the hypothalamus. Neurosci Lett 78:241-246.

Aston-Jones G (2004) Locus coeruleus, A5 and A7 noradrenergic cell groups. In: The rat nervous system, Ed 3 (Paxinos G, ed), pp 259-294. San Diego: Elsevier Academic.

Aston-Jones G, Chiang C, Alexinsky T (1991) Discharge of noradrenergic locus coeruleus neurons in behaving rats and monkeys suggests a role in vigilance. Prog Brain Res 88:501-520.

Baldo BA, Daniel RA, Berridge CW, Kelley AE (2003) Overlapping distributions of orexin/hypocretin- and dopamine-beta-hydroxylase immunoreactive fibers in rat brain regions mediating arousal, motivation, and stress. J Comp Neurol 464:220-237.

Berridge CW, Waterhouse BD (2003) The locus coeruleus-noradrenergic system: modulation of behavioral state and state-dependent cognitive processes. Brain Res Brain Res Rev 42:33-84.

Booth DA (1967) Localization of the adrenergic feeding system in the rat diencephalon. Science 158:515-517.

Boudaba C, Di S, Tasker JG (2003) Presynaptic noradrenergic regulation of glutamate inputs to hypothalamic magnocellular neurones. J Neuroendocrinol 15:803-810.

Bourgin P, Huitron-Resendiz S, Spier AD, Fabre V, Morte B, Criado JR, Sutcliffe JG, Henriksen SJ, de Lecea L (2000) Hypocretin-1 modulates rapid eye movement sleep through activation of locus coeruleus neurons. J Neurosci 20:7760-7765.

Bray GA (2000) A concise review on the therapeutics of obesity. Nutrition 16:953-960.

Brown RE, Sergeeva OA, Eriksson KS, Haas HL (2002) Convergent excitation of dorsal raphe serotonin neurons by multiple arousal systems (orexin/hypocretin, histamine, and noradrenaline). J Neurosci 22:8850-8859.

Calcagnotto ME, Baraban SC (2003) An examination of calcium current function on heterotopic neurons in hippocampal slices from rats exposed to methylazoxymethanol. Epilepsia 44:315-321.

Chemelli RM, Willie JT, Sinton CM, Elmquist JK, Scammell T, Lee C, Richardson JA, Williams SC, Xiong Y, Kisanuki Y, Fitch TE, Nakazato M, Hammer RE, Saper CB, Yanagisawa M (1999) Narcolepsy in orexin knockout mice: molecular genetics of sleep regulation. Cell 98:437-451.

Christie MJ, Williams JT, North RA (1989) Electrical coupling synchronizes subthreshold activity in locus coeruleus neurons in vitro from neonatal rats. J Neurosci 9:3584-3589.

Cunningham Jr ET, Sawchenko PE (1988) Anatomical specificity of noradrenergic inputs to the paraventricular and supraoptic nuclei of the rat hypothalamus. J Comp Neurol 274:60-76.

de Lecea L, Kilduff TS, Peyron C, Gao X, Foye PE, Danielson PE, Fukuhara C, Battenberg EL, Gautvik VT, Bartlett FS, Frankel WN, van den Pol AN, Bloom FE, Gautvik KM, Sutcliffe JG (1998) The hypocretins: hypothalamus-specific peptides with neuroexcitatory activity. Proc Natl Acad Sci USA 95:322-327.

Fadel J, Deutch AY (2002) Anatomical substrates of orexin-dopamine interactions: lateral hypothalamic projections to the ventral tegmental area. Neuroscience 111:379-387.

Fallon JH, Ciofi P (1992) Distribution of monamines within the amygdala. In: The amygdala: neurobiological aspects of emotion memory, and mental dysfunction (Aggleton J, ed), pp 97-144. New York: Wiley.

Foote SL, Morrison JH (1987) Extrathalamic modulation of cortical function. Annu Rev Neurosci 10:67-95.

Gao XB, van den Pol AN (1999) Neurotrophin-3 potentiates excitatory GABAergic synaptic transmission in cultured developing hypothalamic neurones of the rat. J Physiol (Lond) 518:81-95.

Hagan JJ, Leslie RA, Patel S, Evans ML, Wattam TA, Holmes S, Benham CD, Taylor SG, Routledge C, Hemmati P, Munton RP, Ashmeade TE, Shah AS, Hatcher JP, Hatcher PD, Jones DN, Smith MI, Piper DC, Hunter AJ, Porter RA, Upton N (1999) Orexin A activates locus coeruleus cell firing and increases arousal in the rat. Proc Natl Acad Sci USA 96:10911-10916.

Han SK, Chong W, Li LH, Lee IS, Murase K, Ryu PD (2002) Noradrenaline excites and inhibits GABAergic transmission in parvocellular neurons of rat hypothalamic paraventricular nucleus. J Neurophysiol 87:2287-2296.

Hoffman BB, Lefkowitz RJ (1982) Adrenergic receptors in the heart. Annu Rev Physiol 44:475-484.

Hokfelt T, Johansson O, Goldstein M (1984) Central catecholamine neurons as revealed by immunohistochemistry with spectial reference to adrenaline neurons. In: Classical transmitters in the CNS (Bjorklund A, Hokfelt T, eds), pp 157-276. New York: Elsevier.

Horvath TL, Peyron C, Diano S, Ivanov A, Aston-Jones G, Kilduff TS, van den Pol AN (1999) Hypocretin (orexin) activation and synaptic innervation of the locus coeruleus noradrenergic system. J Comp Neurol 415:145-159.

Ishimatsu M, Kidani Y, Tsuda A, Akasu T (2002) Effects of methylphenidate on the membrane potential and current in neurons of the rat locus coeruleus. J Neurophysiol 87:1206-1212.

Ivanov A, Aston-Jones G (2000) Hypocretin/orexin depolarizes and decreases potassium conductance in locus coeruleus neurons. NeuroReport 11:1755-1758.

Jeong SW, Ikeda SR (1998) G protein $\alpha$ subunit G $\alpha$ z couples neurotransmitter receptors to ion channels in sympathetic neurons. Neuron 21:1201-1212.

John J, Wu MF, Boehmer LN, Siegel JM (2004) Cataplexy-active neurons in the hypothalamus: implications for the role of histamine in sleep and waking behavior. Neuron 42:619-634.

Kaslin J, Nystedt JM, Ostergard M, Peitsaro N, Panula P (2004) The orexin/ hypocretin system in zebrafish is connected to the aminergic and cholinergic systems. J Neurosci 24:2678-2689.

Kolaj M, Renaud LP (2001) Norepinephrine acts via $\alpha(2)$ adrenergic receptors to suppress $\mathrm{N}$-type calcium channels in dissociated rat median preoptic nucleus neurons. Neuropharmacology 41:472-479.

Korotkova TM, Eriksson KS, Haas HL, Brown RE (2002) Selective excitation of GABAergic neurons in the substantia nigra of the rat by orexin/ hypocretin in vitro. Regul Pept 104:83-89.

Korotkova TM, Sergeeva OA, Eriksson KS, Haas HL, Brown RE (2003) Excitation of ventral tegmental area dopaminergic and nondopaminergic neurons by orexins/hypocretins. J Neurosci 23:7-11.

Li Y, Gao XB, Sakurai T, van den Pol AN (2002) Hypocretin/orexin excites hypocretin neurons via a local glutamate neuron-A potential mechanism for orchestrating the hypothalamic arousal system. Neuron 36:1169-1181.

Lin L, Faraco J, Li H, Kadotani R, Rogers W, Lin X, Qui X, deJong PJ, Nishino S, Mignot E (1999) The sleep disorder canine narcolepsy is caused by a mutation in the hypocretin (orexin) receptor 2 gene. Cell 98:365-376.

Mallick BN, Majumdar S, Faisal M, Yadav V, Madan V, Pal D (2002) Role of norepinephrine in the regulation of rapid eye movement sleep. J Biosci 27:539-551.

Marcus JN, Aschkenasi CJ, Lee CE, Chemelli RM, Saper CB, Yanagisawa M, Elmquist JK (2001) Differential expression of orexin receptors 1 and 2 in the rat brain. J Comp Neurol 435:6-25.

Mason ST, Fibiger HC (1979) Regional topography within noradrenergic locus coeruleus as revealed by retrograde transport of horseradish peroxidase. J Comp Neurol 187:703-724.

Mitome M, Honma S, Yoshihara T, Honma K (1994) Prefeeding increase in paraventricular NE release is regulated by a feeding-associated rhythm in rats. Am J Physiol 266:E606-E611.

Mochizuki T, Scammell TE (2003) Orexin/hypocretin: wired for wakefulness. Curr Biol 13:R563-R564.

Nishino S, Mignot E (1997) Pharmacological aspects of human and canine narcolepsy. Prog Neurobiol 52:27-78.

Nishino S, Ripley B, Overeem S, Lammers GJ, Mignot E (2000) Hypocretin (orexin) deficiency in human narcolepsy. Lancet 355:39-40.

Peever JH, Lai YY, Siegel JM (2003) Excitatory effects of hypocretin-1 (orexin-A) in the trigeminal motor nucleus are reversed by NMDA antagonism. J Neurophysiol 89:2591-2600.

Peyron C, Tighe DK, van den Pol AN, de Lecea L, Heller HC, Sutcliffe JG, Kilduff TS (1998) Neurons containing hypocretin (orexin) project to multiple neuronal systems. J Neurosci 18:9996-10015.

Rajkowski J, Majczynski H, Clayton E, Aston-Jones G (2004) Activation of monkey locus coeruleus neurons varies with difficulty and performance in a target detection task. J Neurophysiol 92:361-371.

Robbins TW (1984) Cortical noradrenaline, attention and arousal. Psychol Med 14:13-21. 
Saper CB, Chou TC, Scammell TE (2001) The sleep switch: hypothalamic control of sleep and wakefulness. Trends Neurosci 24:726-731.

Sara SJ, Dyon-Laurent C, Herve A (1995) Novelty seeking behavior in the rat is dependent upon the integrity of the noradrenergic system. Brain Res Cogn Brain Res 2:181-187.

Sawchenko PE, Swanson LW (1982) The organization of noradrenergic pathways from the brainstem to the paraventricular and supraoptic nuclei in the rat. Brain Res 257:275-325.

Selden NR, Robbins TW, Everitt BJ (1990a) Enhanced behavioral conditioning to context and impaired behavioral and neuroendocrine responses to conditioned stimuli following ceruleocortical noradrenergic lesions: support for an attentional hypothesis of central noradrenergic function. J Neurosci 10:531-539.

Selden NR, Cole BJ, Everitt BJ, Robbins TW (1990b) Damage to ceruleocortical noradrenergic projections impairs locally cued but enhances spatially cued water maze acquisition. Behav Brain Res 39:29-51.

Smith BN, Davis SF, van den Pol AN, Xu W (2002) Selective enhancement of excitatory synaptic activity in the rat nucleus tractus solitarius by hypocretin 2. Neuroscience 115:707-714.

Sodickson DL, Bean BP (1996) $\mathrm{GABA}_{\mathrm{B}}$ receptor-activated inwardly rectifying potassium current in dissociated hippocampal CA3 neurons. J Neurosci 16:6374-6385.

Takigawa T, Alzheimer C (1999) G protein-activated inwardly rectifying $\mathrm{K}^{+}$(GIRK) currents in dendrites of rat neocortical pyramidal cells. J Physiol (Lond) 517:385-390.

Usher M, Cohen JD, Servan-Schreiber D, Rajkowski J, Aston-Jones G (1999) The role of locus coeruleus in the regulation of cognitive performance. Science 283:549-554.

van den Pol AN (1999) Hypothalamic hypocretin (orexin): robust innervation of the spinal cord. J Neurosci 19:3171-3182.

van den Pol AN, Herbst RS, Powell JF (1984) Tyrosine hydroxylase- immunoreactive neurons of the hypothalamus: a light and electron microscopic study. Neuroscience 13:1117-1156.

van den Pol AN, Ghosh PK, Liu RJ, Li Y, Aghajanian GK, Gao XB (2002) Hypocretin (orexin) enhances neuron activity and cell synchrony in developing mouse GFP-expressing locus coeruleus. J Physiol (Lond) 541:169-185.

Wellman PJ (2000) Norepinephrine and the control of food intake. Nutrition 16:837-842.

Wisor JP, Nishino S, Sora I, Uhl GH, Mignot E, Edgar DM (2001) Dopaminergic role in stimulant-induced wakefulness. J Neurosci 21:1787-1794.

Yamanaka A, Muraki Y, Tsujino N, Goto K, Sakurai T (2003a) Regulation of orexin neurons by the monoaminergic and cholinergic systems. Biochem Biophys Res Commun 303:120-129.

Yamanaka A, Beuckmann CT, Willie JT, Hara J, Tsujino N, Mieda M, Tominaga M, Yagami K, Sugiyama F, Goto K, Yanagisawa M, Sakurai T (2003b) Hypothalamic orexin neurons regulate arousal according to energy balance in mice. Neuron 38:701-713.

Yamuy J, Fung SJ, Xi M, Chase MH (2004) Hypocretinergic control of spinal cord motoneurons. J Neurosci 24:5336-5345.

Yang B, Ferguson AV (2003) Orexin-A depolarizes nucleus tractus solitarius neurons through effects on nonselective cationic and $\mathrm{K}^{+}$conductances. J Neurophysiol 89:2167-2175.

Yoshida Y, Fujiki N, Nakajima T, Ripley B, Matsumura H, Yoneda H, Mignot E, Nishino S (2001) Fluctuation of extracellular hypocretin-1 (orexin A) levels in the rat in relation to the light-dark cycle and sleep-wake activities. Eur J Neurosci 14:1075-1081.

Zeitzer JM, Buckmaster CL, Parker KJ, Hauck CM, Lyons DM, Mignot E (2003) Circadian and homeostatic regulation of hypocretin in a primate model: implications for the consolidation of wakefulness. J Neurosci 23: $3555-3560$. 